\title{
The role of Applied Higher Education in achieving the SDGs. The Example from the Faculty of Vocational Studies at Universitas Airlangga
}

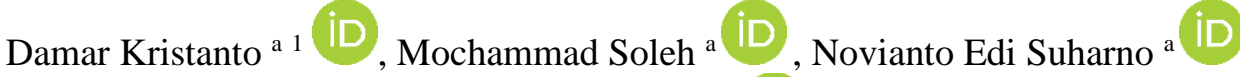 \\ Gagas Gayuh Aji a
}

${ }^{a}$ Department of Business, Faculty of Vocational Studies, Universitas Airlangga, Surabaya

\section{APA Citation:}

Kristanto, D., Soleh, M., Suharno, N.E., \& Aji, G.G. (2021). The role of applied higher education in achieving the SDGs. The example from the Faculty of Vocational Studies at Universitas Airlangga. TIJAB (The International Journal of Applied Business), 5(2), 183-192.

Submission Date: 25/08/2021

Acceptance Date: $24 / 11 / 2021$

\begin{abstract}
The whole world has been made aware of the importance of sustaining human life on this earth. The economic improvement felt in the last decade is the result of increasing industrialization around the world. This has a fairly serious impact in terms of natural damage and social life. Fundamental changes are urgently needed to break the chain of socio-environmental damage that threatens the survival of future generations. These fundamental changes can be started from changes in the concept of education. Education is still considered the key to development both in terms of human resources and innovation. Applied education can be a door in the teaching of new abilities and skills based on the SDGs. This study aims to describe the role of applied or vocational education in achieving SGDs. The Faculty of Vocational Studies at Universitas Airlangga can be an example of how applied higher education institutions have the potential to achieve the SDGs goals. Based on the results of our study, it appears that the role of applied educational institutions has the potential to achieve the SDGs targets. The results of this study have a significant impact on future policy directions and institutional development.
\end{abstract}

Keywords: SDGs; higher education institution; sustainable development; thematic analysis

This is an open access article under the CC BY-NC-SA license.

\section{Introduction}

Since the 17 SDGs were initiated on January 1, 2016, the whole world has been made aware of the importance of sustaining human life on this earth. Human survival is not interpreted in terms of population, increasing wealth, and how one can live in luxury, but how humans have a good quality of life (Segura \& Zamar, 2021).

The economic improvement felt in the last decade is the result of increasing industrialization around the world. This has a fairly serious impact in terms of natural damage, climate change as a consequence

\footnotetext{
${ }^{1}$ Corresponding author.

E-mail address: Damar.Tanto.Academy@gmail.com
} 
of increasingly severe industrial exhaust gases and increasingly uncontrolled waste disposal which in turn can cause ecosystem damage that can threaten the survival of living species (Artyukov et al. 2021). The existing business concept tends to be greedy because it only pays attention to one factor, namely profit as much as possible (Federica \& Celone, 2019) without considering the implications of excessive exploitation of nature and changes in people's consumption patterns which tend to be more excessive, also causing wider social inequality (Nave \& Franco, 2019). Fundamental changes are urgently needed to break the chain of socio-environmental damage that threatens the survival of future generations (Ibanez et al. 2020).

These fundamental changes can be started from changes in the concept of education. Education is still considered the key to development both in terms of human resources and innovation (Wakkee et al. 2019). Future generations must be equipped with a high sensitivity that their world must be cared for properly. High concern for the environment, empathy for people who are in need must be the hallmark of the new generation. So, the world of education has a central role in shaping this mindset (De La Poza et al. 2021).

Higher education has so far been inclined to think about commercialization and business profits (Wakkee et al. 2019). In Indonesia, education is still oriented to the concept of thinking and theorizing, little attention is paid to applied education. The irony is that the application of science that occurs in the field is still oriented to industrial arguments and laws which tend to cause damage because it is more exploitative and requires minimal effort to recover. Applied education can be a door in the teaching of new abilities and skills based on the SDGs (Chaleta et al. 2021). This study aims to describe the role of applied or vocational education in achieving SGDs. The Faculty of Vocational Studies at Universitas Airlangga can be an example of how applied higher education institutions have the potential to achieve the SDGs goals. In addition, this study is also the first stepping stone to make the public aware of the importance of education in achieving the SDGs, secondly to make the public aware that applied education can lead to activities that have a major impact on improving the quality of life of the community.

\section{Literature Review}

\section{SDGs and Higher Education}

The SDGs are a non-profit effort that was initiated for the creation of a better life. If we return to the 17 goals of the SDGs, broadly speaking, the world of education has contributed to goal number 4, namely Quality Education. However, in essence, the world of higher education ultimately teaches and educates human resources so that they can contribute to the world through the abilities and skills they learn, earn a decent living, get social justice, ethical, and can maintain the environment in a sustainable manner (Kioupi \& Voulvoulis, 2020). So that it can be said that the world of education plays a role in all the goals that have been proclaimed.

Return to the nature of higher education, higher education has a key role in the development of human life (Ibanez et al. 2020) through three basic activities, namely teaching, research, and community service. These three basic activities are an effort to improve and get a better quality of life. Society relies heavily on the role of applied universities. The well-being of the community will be helped by the participation of applied universities as a form of implementation of research and applied science to help overcome the difficulties encountered in the community.

Based on SDSN. The 2017 Sustainable Development Report, the educational objectives are: 
1. Give students the knowledge, ability, and motivation to understand that the knowledge they have can be of value to the SDGs.

2. Empower and Mobilize young people to care about their socio-environment

3. Encouraging academic or vocational institutions to implement SDG-based education

4. Provide the widest opportunity from student level to a professional level in developing countries to solve challenges related to the SDGs.

Seeing the magnitude of the goals related to the SDGs, the world of education, especially applied education is the only instrument with a complete role to unite all fields in achieving the SDGs targets so that all higher education agendas should be in line with this (Grano \& Prieto, 2020).

\subsection{Teaching}

Teaching is the nature of higher education which aims to form human resources who have thoughts and understanding of what life is like. Teaching is not only a matter of passing on knowledge to the next generation but rather about shaping the role of individuals to be useful and make a major contribution to society in all fields (Kennedy \& St Brice, 2018). Teaching is not only seen as an effort to achieve SDGs No.4: Quality Education. However, actual teaching is also related to other SDGs. For example, SDGs No.1: No Poverty provides space for universities to provide knowledge so that the human resources produced can work and have better incomes. SDGs No.5: Gender Equality provides space for universities that it is not only men who have the right to learn, women also have the right to get an education equal to men. In addition, higher education also provides space for all elements of society without exception to get the highest education as an effort for SDGs No.10: Reduced inequality (Togo \& Gandidzanwa, 2021).

\subsection{Research and Community Service}

Research is the second nature of higher education which aims to seek new knowledge through research and innovation that increasingly provides solutions to the challenges and problems faced in life. In the case of applied research, research so far has only been seen as an effort to make innovations that are in line with SDGs No.9: Industry, Innovation, and Infrastructure which tends to lead to industrialization, even though the consequence of industrialization is environmental damage which until now requires in-depth research. So that the research role of applied education can also be included in the SDGs related to the environment, such as SDGs No.6: clean water and sanitation, SDGs No.7: Affordable and Clean Energy, SDGs No.13: Climate Action, SDGs No.14: Life Below Water, SDGs No.15: Life on Land. The COVID-19 pandemic is also an example of how important the role of applied research is in finding vaccines and maintaining health during a pandemic, which is the goal of SDGs No.3: Good Health and Well Being.

\section{Method}

For data collection, we traced publications of activities through the website, Instagram, and Facebook of the Faculty of Vocational Studies at Universitas Airlangga. We also do tracing on the Unair News portal regarding the publication of activities carried out by the Faculty of Vocational Studies at Universitas Airlangga. Then, to increase the validity of the data, we conducted document studies including proposals for student organization activities, proposals for community service to the terms of reference for activities of the Faculty of Vocational Studies at Universitas Airlangga. 
The Faculty of Vocational Studies at Universitas Airlangga has 3 departments in charge of health, engineering, and business. In addition, it also has a total of 21 study programs including:

Table 1. Faculty of Vocational Studies at Universitas Airlangga Diploma Programs

\begin{tabular}{lll}
\hline No & Program & Degree \\
\hline 1 & Traditional Healers & Four-year diploma (D4) \\
2 & Physiotherapy & Four-year diploma (D4) \\
3 & Imaging Radiology Technology & Four-year diploma (D4) \\
4 & Nursing & Three -year diploma (D3) \\
5 & Physiotheraphy & Three -year diploma (D3) \\
6 & Medical Laboratory Technology & Three -year diploma (D3) \\
7 & Traditional Healers & Three -year diploma (D3) \\
8 & Dental Engineering & Three -year diploma (D3) \\
9 & Banking Management & Three -year diploma (D3) \\
10 & Office Administration & Three -year diploma (D3) \\
11 & Accounting & Three -year diploma (D3) \\
12 & Taxation & Three -year diploma (D3) \\
13 & Marketing Management & Three -year diploma (D3) \\
14 & Hospitality Management & Three -year diploma (D3) \\
15 & Veterinary Paramedics & Three -year diploma (D3) \\
16 & Library & Three -year diploma (D3) \\
17 & Tourism & Three -year diploma (D3) \\
18 & Automation Instrumentation System & Three -year diploma (D3) \\
19 & Information System & Three -year diploma (D3) \\
20 & Occupational Health and Safety & Three -year diploma (D3) \\
21 & English & Three -year diploma (D3) \\
\hline
\end{tabular}

Looking at the profile of the Faculty of Vocational Studies at Universitas Airlangga shows that the potential for multi-sector activities that support the achievement of the SDGs is very relevant. Therefore, the Faculty of Vocational Studies at Universitas Airlangga is the right subject for this study.

The range of activities that we recorded were activities from January 1, 2020, to August 13, 2021. After the data was collected, we compiled a database of activities and then we conducted a further study of which activities could be assessed as supporting the SDGs. To examine the document, we use thematic analysis methods that are useful for classifying and mapping a phenomenon. Based on the tracing results, at least 116 activities that support the SDGs have been recorded.

\section{Results}

The Faculty of Vocational Studies at Universitas Airlangga has a uniqueness that is very rarely owned by other similar applied educational institutions. The uniqueness of the Vocational Faculty is that three different fields of applied science can intersect and synergize, namely Health, Engineering, and Business. This uniqueness provides enormous potential in the creation of a sustainable industrial ecosystem. This is evidenced by the considerable participation of the Faculty of Vocational Studies at Universitas Airlangga in activities that uphold the achievement of the SDGs targets.

Table 2. SDGs achieved by the Faculty of Vocational Studies at Universitas Airlangga

\begin{tabular}{lllll}
\hline SDGs & $\begin{array}{l}\text { Student } \\
\text { Bodies }\end{array}$ & Faculty & Public & $2020-2021$ \\
& 5 Services & \\
\hline 1. No Poverty & 5 & 0 & 5 & 10 \\
2. Zero Hunger & 2 & 2 & 1 & 5 \\
3. Good Health and Well-Being & 14 & 1 & 14 & 29
\end{tabular}


4. Quality Education

5. Gender Equality

8. Decent Work and Economic Growth

9. Industry Innovation and Infrastructure

16. Peace, Justice and Strong Institution

17. Partnership for the goal

TOTAL

\begin{tabular}{llll}
11 & 7 & 19 & 37 \\
1 & 0 & 0 & 1 \\
3 & 0 & 11 & 14 \\
1 & 6 & 6 & 13 \\
2 & 0 & 0 & 2 \\
0 & 3 & 2 & 5 \\
39 & 19 & 58 & 116 \\
\hline
\end{tabular}

At least 116 activities were recorded from these three fields and can be classified into 9 of the 17 SDGs proclaimed by the United Nation. Based on the table 1, 39 SDGs activities have been carried out by student bodies, 19 by faculties, and 58 by lecturers who carry out community service activities.

Table 3. Examples of activities worth achieving the SDGs

\begin{tabular}{ll}
\hline SDGs & Example \\
\hline 1. No Poverty & "Get Out of Your Box and Chase Your Dream With \\
& Scholarship" - A Scholarship Program \\
2. Zero Hunger & $\begin{array}{l}\text { Cheap Food Market - "With Loving Students Care for the } \\
\text { People of the Country" } \\
\text { Gresik Volunteer Students are tough. - "Help Accelerate }\end{array}$ \\
3. Good Health and Well-Being & Herd Immunity, Nursing Students Become Vaccination \\
& Volunteers". \\
& Tax Training - "Digitalization of Industrial Taxation Class \\
& Program" \\
4. Quality Education & The competition entitled "We Do Action" (Commemorating \\
& World Women's Day) \\
5. Gender Equality & Digitizing Micro, Small and Medium Enterprises (MSMEs) \\
& in Recording Financial Statements and Online Marketing at \\
the East Java IKM Forum (FIJ) Bojonegoro Branch as a & Strategy for Economic Recovery in a Pandemic Period \\
8. Decent Work and Economic Growth & OSTA APP (Osteo Porosis Self Assesment) \\
& Easter Service "Life in Him is all glory" \\
& Industrial Cooperation and Partnership \\
9. Industry Innovation and Infrastructure &
\end{tabular}

\subsection{Teaching The Role of Student Bodies}

The sustainability of the SDGs program cannot be separated from the role of students. Students are one of the good pillars in generating innovations and ideas for activities that have SDG values. Students participate through academic and non-academic activities, one of which is taking a role in implementing the SDGs program. The main principle of the SDGs is "leave no one behind". So of course the SDGs have been designed to encourage all parties to participate, including students.

Students have an important role, namely as agents of change who are required to think critically and be responsive in dealing with problems around them. They have to think about how to make an impact on changes in the socio-environmental conditions that occur around them. Students are also a moral force to maintain the values that are embedded and organized in society. Students also have a role as social controllers. Students are required to be sensitive to gaps both socially and changes in environmental and natural conditions around them. Students must be able to play themselves as defenders of the weak so that social inequality does not widen as well as the criticality of students in the 
event of excessive exploitation of nature which has the potential to increase natural damage which will also have an impact on the weak and disadvantaged communities.

Students seem to be the main actors in the success of universities in their participation in building a better life following the goals of the SDGs. Currently, students are required not only to learn from what is given by their lecturers in the classroom. However, students must also gain experience in the community by applying what they have learned during the lecture process. In this case, students act as agents who bridge communication between universities and the community. The activities of student organizations should be focused on activities that have a major impact on increasing the quality of life of the community.

Thus, the student community must have programs related to the SDGs so that they have a changing impact on people's lives. The use of the budget for student activities should be used for meaningful programs, not only student development in terms of skills, but programs that practice student skills for the community. Thus, the use of the budget will certainly be more effective and efficient in achieving the SDGs targets through student activities.

\subsection{Teaching The Role of Student Bodies Faculty Activities}

Education institutions is increasingly shifting towards capitalist thinking. The role of educational institutions that used to be to form good human resources so that they can play a role in society and change the quality of people's lives for the better seems to be starting to fade. now higher education institutions are positioning themselves more as industrial partners oriented to projects that lead to the formation of material benefits so that the social factors of higher education are questioned. For this reason, the world demands the role of universities in achieving the SDGs. Through various rankings such as THE (Times Higher Education) for SDGs goal which ranks universities around the world on their participation in supporting the achievement of the SDGs. For this reason, faculty activities in all universities should lead to the achievement of these SDGs. The Faculty of Vocational Studies at Universitas Airlangga is a good example, how the three departments in it are examples of the synergy in the fields of Health, Engineering, and Business which in its meaning represent the main fields of people's lives.

Faculty activities are a form of existence of the faculty to show the extent to which knowledge has been developed, achievements, innovations, and competitive advantages that may not be carried out by competing institutions. However, these activities are now a separate concern when the activities held do not have an impact on changes in people's living conditions, only as a tool to spend the budget, and are not even relevant to efforts to increase student capacity. Faculty activities should be oriented towards increasing the expertise of both teaching staff, staff, and students with the hope that this capacity increase will be the faculty's initial capital to participate in the achievement of the 17 SDGs goals starting with the achievement of SDGs number 16, namely a resilient institution.

If the initial capital has been met, the faculty can start making activities with the nuances of the SDGs. The Faculty of Vocational Studies at Universitas Airlangga has good capital because it has 3 scientific fields namely health, engineering, and business which intersect with each other. This 
multidisciplinary nature is mutually reinforcing and in line with the nature of the 17 SDGs goals proclaimed by the United Nation.

The Faculty of Vocational Studies at Universitas Airlangga must have a roadmap of activities and division of labor so that the activities of the faculty will be more directed, on target, and evenly distributed for all fields of study in their study programs.

\subsection{Community Service}

Community service is a tangible form of how the world of education assists the community directly. Often the world of education still assists the community in the form of additional knowledge as a form of inclusive education. However, the world of education should be able to take advantage of community service programs as a forum for not only knowledge transfer, but technology transfer. Applied higher education has a high potential to fill this role vacancy. Applied higher education has a paradigm on tangible outcomes such as products and technology so that applied higher education will be able to have a more real impact on improving people's technical abilities to create and update products and innovations in their business.

Based on the tracing results, it can be seen that community service is the most dominant activity. Community service is a form of participation and the role of universities in improving people's lives, starting from the local community to the global level. Community service is an activity that can have a real direct impact because it brings together professionals and academics to transmit knowledge, knowledge, and expertise to the community, to make people experience increased abilities and be able to improve their standard of living. Seeing this nature, community service is the core role of the academic world in achieving the global goals of the SDGs.

Community service carried out by the Faculty of Vocational Studies at Universitas Airlangga can be an example of the achievement of the SDGs. The trials that have been carried out have characterized the transfer of knowledge that is technical and supports community capacity building. So not only knowledge is given but also how to do or technical application of science.

\subsection{Project-Based Learning for SDGs learning}

To achieve the global goals of the SDGs and to accelerate the improvement of people's living standards, it is necessary to start with a reform of the educational paradigm. Education, which was initially considered only to provide knowledge to students and only oriented to spawn theoretical and critical abilities, did not appear to be sufficient in making significant changes in improving the quality of life of the community. The paradigm of learning in the classroom seems to have begun to be shifted towards a more practical one.

Applied abilities seem to have to be given to students from an early age so that mastery of science is also equipped with mastery of tools and methods. When graduates have mastery of tools and methods and are even able to spawn new methods and can make innovations, it is hoped that the younger generation will have sufficient capital to determine the direction of their lives and have a good and more sustainable quality of life not only in terms of income, but also be able to care for the nature around them.

Project-based learning seems to be one example of how the flow of knowledge development and knowledge transfer runs continuously. Figure 1 shows that students should receive more material in the real field. When a student receives and learns theory in the classroom, the student should apply it in real 
terms in the form of real practice that is in direct contact with society. This intersection will provide students with material and cases that they must solve so that they receive a lesson, both knowledge that is not given in class, and they can understand what society needs. Students practice the knowledge learned in a project that they hold and the project is socially oriented, the results of the project must have real benefits in changing living conditions for the better. Then students report their work to the study program. This form of learning will be more meaningful in achieving the goals of SDGs and applied education organized by the Faculty of Vocational Studies at Universitas Airlangga has great potential when implementing this kind of learning model.

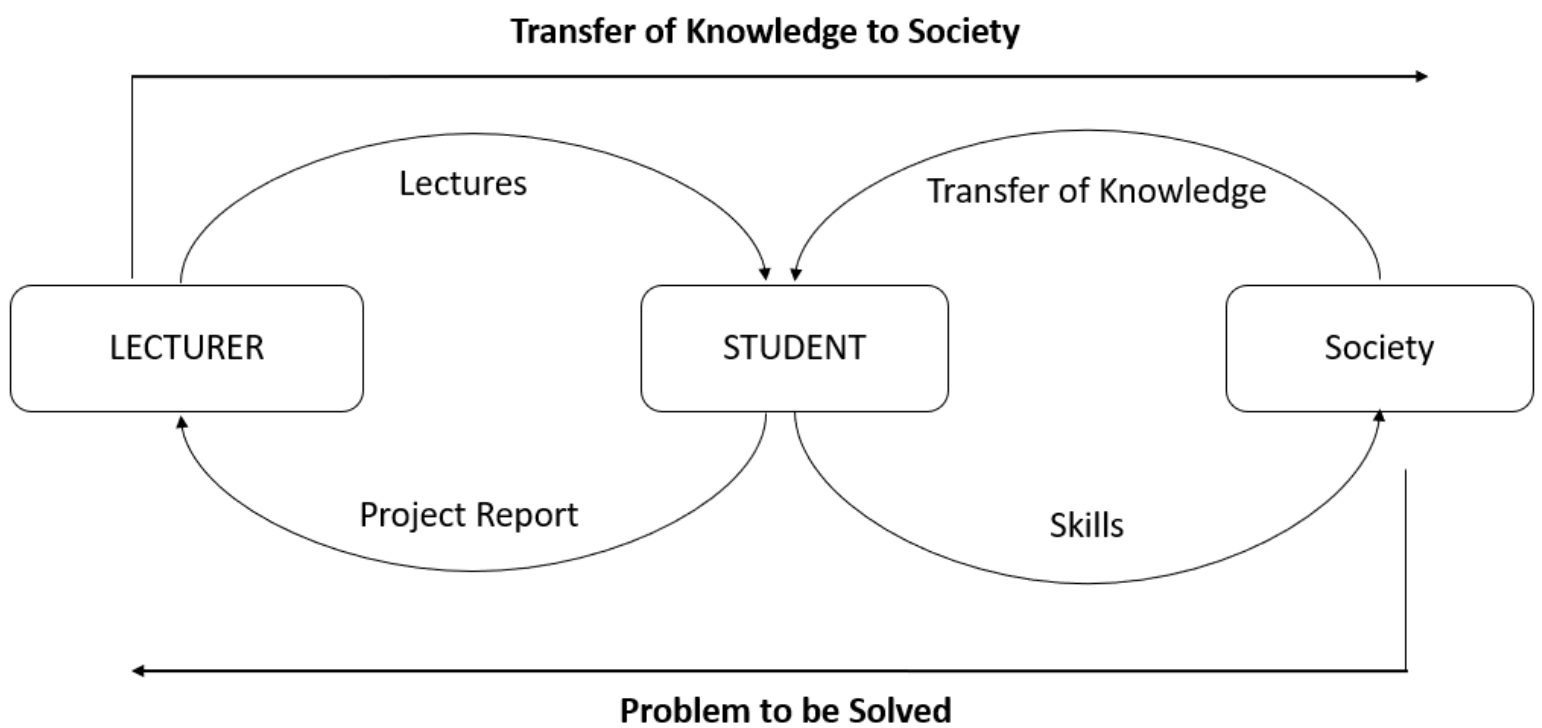

Figure 1. Transfer of knowledge to the community in order to achieve the SDGs

\section{Conclusion}

Based on the results of our study, it appears that the role of applied educational institutions has the potential to achieve the SDGs targets. The Faculty of Vocational Studies at Universitas Airlangga provides an example of how an applied educational institution can make a major contribution in efforts to eradicate poverty, hunger, health, improve public education and harmonize industrial relations with environmental protection. The top five SDGs that are the mainstay of the Vocational Faculty are in terms of Quality Education, Good Health and Well-Being, Decent Work and Economic Growth, Industry Innovation and Infrastructure, and No Poverty. These five SDGs must be the main point of activities to achieve a better life.

The results of this study have a significant impact on future policy directions and institutional development. First, applied educational institutions can find out their capabilities and their role in participating in the achievement of the SDGs. It is not necessary to fulfill the 17 SDGs, but focusing on certain SDGs will make more contributions that have a big impact on life. Second, applied educational institutions can map out which fields of science can make a major contribution. The spirit of SDGs should be included in courses that have the potential to provide learning to students whose work can then be enjoyed by many audiences and can boost the quality of life of the community. At last, this study can provide additional input to assist stakeholders in applied education institutions in terms of policy directions that have a large impact on the lives of many people. 


\section{References}

Abad-Segura, E., \& González-Zamar, M. D. (2021). Sustainable economic development in higher education institutions: A global analysis within the SDGs framework. Journal of Cleaner Production, 294, 126133.

Artyukhov, A., Volk, I., Vasylieva, T., \& Lyeonov, S. (2021). The role of the university in achieving SDGs 4 and 7: a Ukrainian case. In E3S Web of Conferences (Vol. 250). EDP Sciences.

Chaleta, E., Saraiva, M., Leal, F., Fialho, I., \& Borralho, A. (2021). Higher Education and Sustainable Development Goals (SDG) - Potential Contribution of the Undergraduate Courses of the School of Social Sciences of the University of Évora. Sustainability, 13(4), 1828.

Cordova, M. F., \& Celone, A. (2019). SDGs and innovation in the business context literature review. Sustainability, 11(24), 7043.

De la Poza, E., Merello, P., Barberá, A., \& Celani, A. (2021). Universities' Reporting on SDGs: Using THE Impact Rankings to Model and Measure their Contribution to Sustainability. Sustainability, 13(4), 2038.

Esteban Ibáñez, M., Lucena Cid, I. V., Amador Muñoz, L. V., \& Mateos Claros, F. (2020). Environmental education, an essential instrument to implement the sustainable development goals in the university context. Sustainability, 12(19), 7883.

Grano, C., \& Prieto, V. C. (2020). Sustainable Development Goals in Higher Education. In 26th IJCIEOM-International Joint Conference on Industrial Engineering and Operations Management., Rio de Janeiro.

Nave, A., \& Franco, M. (2019). University-Firm cooperation as a way to promote sustainability practices: A sustainable entrepreneurship perspective. Journal of Cleaner Production, 230, 11881196.

Richards-Kennedy, S., \& St Brice, L. (2018). Knowledge brokerage, SDGs and the role of universities. Social and Economic Studies, 67(4), 7-276.

SDSN. Sustainable Development Report. Global Responsibilities. International Spillovers in Achieving the Goals. 2017. Available online: https://www.sdgindex.org/reports/sdg-index-and-dashboards2017/ (accessed on 1 October 2021).

Togo, M., \& Gandidzanwa, C. P. (2021). The role of Education 5.0 in accelerating the implementation of SDGs and challenges encountered at the University of Zimbabwe. International Journal of Sustainability in Higher Education.

Wakkee, I., van der Sijde, P., Vaupell, C., \& Ghuman, K. (2019). The university's role in sustainable development: Activating entrepreneurial scholars as agents of change. Technological Forecasting and Social Change, 141, 195-205. 


\title{
Peran Perguruan Tinggi Terapan dalam pencapaian SDGs. Contoh dari Fakultas Vokasi Universitas Airlangga
}

\begin{abstract}
Abstrak
Seluruh dunia telah disadarkan akan pentingnya mempertahankan kehidupan manusia di bumi ini. Perbaikan ekonomi yang dirasakan dalam dekade terakhir ini merupakan hasil dari meningkatnya industrialisasi di seluruh dunia. Hal ini berdampak cukup serius dalam hal kerusakan alam dan kehidupan sosial. Perubahan mendasar sangat diperlukan untuk memutus mata rantai kerusakan sosial lingkungan yang mengancam kelangsungan hidup generasi mendatang. Perubahan mendasar tersebut dapat dimulai dari perubahan konsep pendidikan. Pendidikan masih dianggap sebagai kunci pembangunan baik dari segi sumber daya manusia maupun inovasi. Pendidikan terapan dapat menjadi pintu dalam pengajaran kemampuan dan keterampilan baru berdasarkan SDGs. Penelitian ini bertujuan untuk mendeskripsikan peran pendidikan terapan atau vokasional dalam pencapaian SGDs. Fakultas Vokasi Universitas Airlangga dapat menjadi contoh bagaimana perguruan tinggi terapan memiliki potensi untuk mencapai tujuan SDGs. Berdasarkan hasil kajian kami, terlihat bahwa peran lembaga pendidikan terapan berpotensi untuk mencapai target SDGs. Hasil penelitian ini memiliki dampak yang signifikan terhadap arah kebijakan dan pengembangan kelembagaan ke depan.
\end{abstract}

Kata kunci: SDGs, institusi pendidikan tinggi, pembangunan berkelanjutan, analisis tematik 